\title{
Antoni SKOWROŃSKI*
}

\section{Utrzymanie dynamicznej równowagi ekosystemów Ziemi.}

\section{(Przyrodnicze i antropogeniczne mechanizmy)}

Przed kilkunastoma miliardami lat osobliwość zwana „Wielkim Wybuchem", zapoczątkowala stopniowa ewolucję obserwowanego obecnie Wszechświata. Rozchodząca się w przestrzeni kosmicznej materia i energia zaczęła gromadzić się $w$ pewnych miejscach i grawitacyjnie oddziaływać na otoczenie. Coraz wyraźniejsze ośrodki kondensacji materii dały początek planetom, wśród których w Układzie Słonecznym znalazła się Ziemia. Do tej pory brak jest naukowej wiedzy, w jakim stopniu warunki panujące na naszej planecie są unikatowe. Wiadomo jednak, że chociażby w naszym Układzie Słonecznym panują skrajnie zróżnicowane warunki. $\mathrm{Na}$ ich tle środowisko Ziemi jest wyjątkowe. Grawitacyjna selekcja pierwiastków doprowadziła do specyficznego rozmieszczenia nawzajem przenikających się sfer tworzących charakterystyczną przestrzeń naszej planety. Przestrzeń ta wypełniona materialnymi elementami tworzy środowisko przyrodnicze, które jest systemem złożonym, składającym się z wielu podsystemów różnego rodzaju, pozostających we wzajemnych związkach i wzajemnie na siebie wpływających ${ }^{1}$. Głównymi podsystemami środowiska przyrodniczego Ziemi są: atmosfera, hydrosfera, litosfera i biosfera.

W historii naszego globu zaistniały unikalne, nigdy później nie występujące warunki, sprzyjające powstaniu osobliwego stanu jakim jest życie. Nie jest łatwo streścić współczesne poglądy na powstanie i rozwój życia na Ziemi. Nadal nauka nie zna wszystkich czynników decydujących o jego zaistnieniu. Zgodzić się jednak trzeba, że wyjątkowe warunki jakie w pewnym czasie zaistniały w przestrzeni geograficznej Ziemi, doprowadziły do powstania coraz bardziej złożonych molekuł, z połączenia których zrodziło się życie. W miarę zmieniających się warunków środowiska, życie przybierało coraz to nowe formy, zawsze przystosowując się do zmian zachodzących $w$ otoczeniu. W procesie ewolucji wyłaniały się bardziej złożone organizmy, tworząc $w$ ten sposób różne poziomy orga-

* Instytut Ekologii i Bioetyki, UKSW w Warszawie.

1 Por. A. RICHLING, J. SOLON, Ekologia krajobrazu, PWN, Warszawa 1994, s. 13. 
nizacji biologicznej o zróżnicowanym stopniu złożoności strukturalnej i funkcjonalnej. Od organizmu poprzez populację aż do biocenozy i ekosystemu, mamy do czynienia $z$ wyższymi poziomami organizacji biologicznej, którą zwykło się określać mianem układów ekologicznych. Są one zintegrowanymi jednostkami, gdzie odbywa się ciągła przemiana materii, przepływ energii i przekaz informacji. Dynamiczna równowaga tych układów ekologicznych zapewnia trwanie życia na Ziemi.

\section{Biosfera}

Życie na Ziemi można zaobserwować na jej powierzchni i w górnej warstwy litosfery, (do $3 \mathrm{~m} \mathrm{w}$ głąb Ziemi niżej spotykane są tylko bakterie), w dolnej części atmosfery (do wysokości kilkuset metrów wyżej umieszczone są bakterie, zarodniki i najdrobniejsze owady) oraz w całej hydrosferze (we wszystkich wodach śródlądowych, oceanach i morzach) $)^{2}$. Tę sferę życia przenikającą inne strefy, nazywamy biosferą.

Termin "biosfera" pochodzi od dwóch greckich słów: bios i sphaira. Słowo bios w jęz. greckim oznacza życie, czas trwania życia, środki do życia; świat w którym żyjemy. Natomiast słowo sphaira - piłkę, kulę, kulę ziemską, kulistą przestrzeń nieba okalającą Ziemię. Najprościej ujmując, termin "biosfera” oznacza sferę kuli ziemskiej, w której występuje życie. Biosfera to także wzajemne zależności między materią żywą a nieożywioną. Dlatego też możemy powiedzieć, że "biosfera to heterogenny system ekologiczny, obejmujący cały świat ożywiony i jego środowisko"3 $^{\prime \prime}$. Jest to system ekologiczny, w którym pod wpływem organizmów żywych stanowiących ważną siłę biogeochemiczną, dokonują się ciągłe przekształcenie powierzchni Ziemi, gleby, skał, atmosfery, hydrosfery i kosmosfery wskutek migracji i deferencjacji pierwiastków chemicznych ${ }^{4}$. Biosfera stanowi zatem pewien rodzaj całości, wewnętrznie powiązanej przez przepływ materii i energii, w której zachodzi bezpośrednie oddziaływanie żywej materii na wiele procesów przyrodniczych ${ }^{5}$. Warunkiem ciagłego istnienia życia na Ziemi jest utrzymanie zamkniętego obiegu pierwiastków, to znaczy zbilansowania procesów produkcji i dekompo-

2 Por. J. M. DOŁĘGA, Cztowiek w' zagrożonym środowisku. $Z$ podstawowych zagadnień sozologii, wydanie II poprawione, Wyd. ATK, Warszawa 1998, s. 143.

3 Za. B. STUGREN, Zasady ekologii ogólnej, PWN, Warszawa 1976, s. 51; por. także: F. J. SZIPUNOW, Organizowannost' biosfery, Nauka, Moskwa 1980, s. 15; Biosfera, Stownik wyrazón obcych, pod. red. naukową J. Tokarskiego, PWN, Warszawa 1971, s. 81, 83.

4 Por. J. M. DOEEGA, Czlowiek w' zagrożonym środowisku..., dz. cyt., s. 144.

5 G. DOBRZAŃSKI, Przyrodnicze podstaw'y achrony biosfery i ekosystemów, w: Interdyscyplinarne podstaw'y ochrony środowiska przyrodniczego. Kompendium do nauczamia i studiowania, Zakład Narodowy im. Ossolińskich, Wrocław -Warszawa-Kraków, 1993, s. 25. 
zycji. Pełne zbilansowanie możliwe jest tylko w skali całej biosfery i w przedziale długiego czasu. Układ, który realizuje proces produkcji i dekompozycji, wykorzystując do tego energię i podtrzymując cykl obiegu pierwiastków, nazywamy ekosystemem ${ }^{6}$. Cała biosfera jest zatem wielkim ekosystemem, chociaż proces produkcji i dekompozycji zazwyczaj zamyka się na mniejszym obszarze.

\section{Ekosystem}

Definicja ekosystemu jest niejednolita i zazwyczaj przyjmowana w sposób umowny ${ }^{7}$. Bardzo ogólnie możemy powiedzieć, że ekosystem to "zespół żywych organizmów tworzących biocenozę łącznie ze wszystkimi elementami środowiska nieożywionego, czyli z biotopem. Każdy naturalny

6 W strukturze biosfery można wyróżnić układy ekologiczne niższego rzędu: biomy, zlewnie, krajobrazy i najbardziej podstawowe - ekosystemy, zwane niekiedy komórkami biosfery.

7 J. Wejner w swojej książce: Życie i ewolucja biosfery. Podręcznik ekologii ogólnej, PWN, Warszawa 1999, podaje na ss. $192-193$ ramkę z zestawieniem różnych definicji pojęcia ekosystem. Np.: 1), ,Termin ekosystem można zdefiniować jako system środowiskowy i system biotyczny współdziałające ze sobą. Czynności zespołu można streścić jako akcję (działanie) siedliska fïzykochemicznego wywieraną na organizmy, reakcję organizmów na czynniki fizyczne i koakację (wzajemne oddzialywanie) organizmów na siebie nawzajem. (Clements i Shelford, 1939), za: W. C. ALLEE, A. E. EMERSON, O. PARK, T. PARK, K. P. SCHMIDT, Zasady ekologii zwierzqt, PWN, Warszawa 1958, (Wyd. oryginalne 1950); 2) „Każda przestrzeń (stanowiąca pewną całość pod względem przyrodniczym), w której zachodzi stała wymiana materii pomiędzy jej żywą i nieożywioną częścią, jako wynik wzajemnego oddziaływania żywych organizmów i martwych substancji mineralnych jest układem ekologicznym, czyli ekosystemem". Za: E. P. Odum, Podstawy ekologii, PWRiL, Warszawa 1963, (Wyd. oryginalne 1959); 3) „Ekosystem można zdefiniować jako jednostkę środowiska złożoną z różnych biotycznych i abiotycznych składników, które powiązane są ze sobą procesami wymiany związków chemicznych i energii. Mówiąc prościej na ekosystem składają się wszystkie zamieszkujące dane środowisko organizmy oraz abiotyczne elementy ich środowiska". Za: B. D. COLLIER, G. W. COX, A. W. JOHNSON, PH. C. MILLER, Ekologia dynamiczna, PWRiL, Warszawa 1978, (Wyd. oryginalne 1973); 4) ,[Ekosystem jest to] ...3wymiarowy wycinek biosfery, system otwarty, który w idealnych warunkach utrzymuje stan stacjonarny: $\mathrm{aCO}_{2}+\mathrm{xM}++\mathrm{yA}-+(\mathrm{y}-\mathrm{x}) \mathrm{H}++\mathrm{zH}_{2} \mathrm{O}+$ Energia $\left(\mathrm{C}_{\mathrm{a}} \mathrm{H}_{2 \mathrm{z}} \mathrm{O}_{z} \mathrm{M}_{\mathrm{x}} \mathrm{A}\right)+(\mathrm{a}+\ldots)$ $0_{2}$. Elementami ekosystemu są gatunki". Za: B. Urlich, Stabillity, elasticity, and resilience in terrestrial ecosystems with respect to matter balance. W: Potentials and limitations of ecosystem analisis, pod. red. E-D. Schulze, H. Zwőfler, Springer, Heidelberg 1987; 5) „[Ekosystem jest to] ...wzrokowo rozpoznawalna jednostka w przyrodzie, odgraniczona ekotonem, złożona z zespołów, w których krążą biologicznie ważne pierwiastki chemiczne (CNSP itd.). Te pierwiastki krążą szybciej wewnątrz ekosystemu niż między ekosystemami. Przykłądem są: staw, las, zarośla”. Za: M. B. RAMBLER, L. MARGULIS, R. FOSTER, Global ecology, Academic Press, Boston 1989. Inne terminy używane zamiast słowa ,ekosystem" to: mikrokosmos, holocen, biosystem, ,bioinert body”, biocenoza, pleocen, fizjocenoza, biogeocenoza $\mathrm{i}$ inne. 
ekosystem stanowi układ otwarty i funkcjonuje dzięki przepływowi energii i krążeniu materii" ${ }^{8}$. Ekosystem można też określić jako zbiór różnych populacji lub „system o swoistym uporządkowaniu, który podtrzymuje i powiększa swoje uporządkowanie" . Ekosystem, to „naturalna całość środowiska przyrodniczego na określonym obszarze, w której zachodzi nieprzerwany przepływ energii i materii między biocenozą a częścią abiotyczną środowiska, w zasadzie samowystarczalną i o zamkniętym obiegu łańcucha pokarmowego"10. Pojęciem ekosystemu obejmuje się zatem różne co do wielkości i złożoności układy ekologiczne.

Ekosystem jest najbardziej złożoną jednostką ekologiczną. Jest to układ ze współdziałającymi wszystkimi poziomami troficznymi (pokarmowymi) - producentami, konsumentami i reducentami - zintegrowany $\mathrm{z}$ abiotycznym środowiskiem. Funkcjonowanie każdego ekosystemu, polega na obiegu materii i przepływie energii. Cykle obiegu materii oraz przepływu energii $w$ ekosystemie są mniej lub bardziej zamknięte. W analizie bardziej szczegółowej ekosystem jest pojmowany jako „dowolny fragment biosfery, w którym grupa organizmów realizuje procesy produkcji i dekompozycji, przy chociaż częściowo zamkniętym obiegu materii, z wykorzystaniem przepływającej przez ten system energii"11. Elementami nieożywionymi ekosystemu są pule związków chemicznych: akceptorów i donorów elektronów, substratów mineralnych i organicznych ${ }^{12}$. Stabilność ekosystemu zapewniają istniejące $w$ wewnątrz i na zewnątrz tego systemu sprzężenia zwrotne oraz wewnętrznie wykształcone procesy regulacyjne. Tak więc ekosystemy są w miarę autonomicznymi ale zintegrowanymi jednostkami o swoistych wlaściwościach i współzależnościach wewnętrznych elementów i wzrastającej wewnętrznej złożoności oraz samoregulacji.

\section{Fizykochemiczne procesy podtrzymujące życie na Ziemi}

Równowaga i stabilność tak pojmowanych jednostek biologicznych, polega na niezachwianym przepływie energii, materii i informacji ${ }^{13}$. Ener-

8 E. PAŁYGA-GUTOWSKA, Ekologia z ochrona środowiska. Przewodnik, wyd. III poprawione, Wyd. Oświata, Warszawa 1998, s. 52.

9 S. ZIĘBA, Bioróżnorodność strategiq organizacji biosfery, „Człowiek i Przyroda”, 1999, nr 10, s. 26-27.

10 K. R. MAZURSKI, Podstawy sozologii. Kompendium wiedzy o niszczeniu i ochronie środowiska, Wyd. Sudety, Wrocław 1998, s. 32.

11 J. WEINER, Życie i ewolucja biosfery..., dz. cyt., s. 194.

12 Tamże.

13 Por. W. NIEDBAŁA, Ekologia - organizmy żywe i ich środowisko, w: Kompendium wiedzy o ekologii, pod red. J. Strzałko i T. Mossor-Pietraszewskiej, PWN, Warszawa-Poznań 2001, s. 43. 
gia w ekosystemach przepływa jednokierunkowym strumieniem w układzie otwartym, a najważniejszym źródłem energii w ekosystemach jest energia słoneczna. Przepływ energii stanowi istotę życia, ponieważ organizmy są układami termodynamicznymi, w których dokonuje się praca. W układach ekologicznych (ekosystemach) następuje ciągła zmiana sekwencji energii od promieniowania słonecznego poprzez energię wiązań chemicznych do ciepła i formy pracy, rozumianej jako nakład energii wyzwolonej z przekształcenia wiązań chemicznych $w$ zgodzie $z$ prawami termodynamiki ${ }^{14}$. W ekosystemach ekologicznych prawie wszystko można przeliczyć na energię. Wyliczając bilans energetyczny biosfery, dla przykładu można podać, że produkcja na lądzie (łącznie ze słodkowodną) sięga $133 \times 10^{9}$ ton suchej masy; produkcja w morzach aż $91,6 \times 10^{9}$ ton suchej masy, czyli sumaryczna produkcja roczna na Ziemi miałaby wynosić aż $224,6 \times 10^{9}$ tony suchej masy. Jest to prawie $9 \times 10^{21} \mathrm{~J}$, co odpowiada mocy $285 \times 10^{\circ} \mathrm{MW}$, stanowiąc $0,1-0,3 \%$ rocznego promieniowania słonecznego docierającego do Ziemi (całkowitego zakresu falowego, o mocy $80,9 \times 10^{9} \mathrm{MW}$ ). $20 \%$ energii słonecznej jest wykorzystane w cyklach hydrologicznych, ale większość tej energii jest niewykorzystana ${ }^{15}$.

Energia jest najbardziej uniwersalną zmienną ekosystemów i dotyczy wszystkich organizmów wchodzących w skład ekosystemu bez względu na to, jaki typ metabolizmu je napędza i z jakich substratów korzystają. Energia ta jest wykorzystana do podstawowych procesów metabolicznych i budowy własnych struktur organizmów, ale część tracona jest bezpowrotnie w postaci ciepla.

Drugim ważnym procesem podtrzymującym życie na Ziemi, jest wymianie pierwiastków niezbędnych dla żywych organizmów. Pierwiastkami najbardziej rozpowszechnionymi we Wszechświecie są: $\mathrm{H}, \mathrm{He}, \mathrm{O}, \mathrm{C}$, $\mathrm{N}, \mathrm{Ne}, \mathrm{Mg}$, Si, Fe, S, Ar, Al, Co, Na, Ni, Cu, P, Cl, K. Natomiast niezbędne dla żywych organizmów, czyli tzw. pierwiastki biogenne, biofilne, odżywcze lub życiodajne, to: H, O, C, S, P, N. Organizmy żywe przyswajają te pierwiastki $w$ postaci sobie dostępnej. Ta wymiana dokonuje się na drodze krążenia materii. Krążenie materii na powierzchni Ziemi trwa bezustannie i odbywa się nawet bez udziału jakichkolwiek układów żywych. Jednak na obecnym poziomie organizacji życia, w obiegu materii biorą udział producenci, konsumenci i reducenci, a przynajmniej producenci i reducenci ${ }^{16}$. Trwanie życia na Ziemi jest możliwe dzięki osobliwym reakcjom fizyko-chemicznym, w których część organizmów rozkła-

14 Por. E. PAEYGA-GUTOWSKA, Ekologia $z$ ochrona Srodowiska.., dz. cyt., s. 52; także: J. WEINER, Życie i ewolucja biosfery..., dz. cyt., s. 203-204.

15 Zob. tamże, s. 123.

16 Por. B. HALICZ, Podstawy biologii, PWN, Warszawa 1976, s. 57-59; A. RICHLING, J. SOLON, Ekologia krajobrazu, Wyd. IV, PWN, Warszawa 2002, s. 103-104. 
da (dekomponuje) materię organiczną wyprodukowaną $z$ prostych związków przez inne organizmy żywe.

Naturalny cykl krążenia pierwiastków w biosferze polega na przemieszczaniu się pierwiastków chemicznych ze środowiska abiotycznego do organizmów i z organizmów do środowiska. Pierwiastki biogenne schwytane $\mathrm{w}$ sieć troficzną ekosystemu poprzez jednego $\mathrm{z}$ autotrofów, są wprowadzane do łańcuchów troficznych, które się albo rozgałęziają, albo tworzą pętlę, gdzie atom może krążyć prze dłuższy czas. Są to liczne bezkierunkowe i kierunkowe relacje zachodzące pomiędzy poszczególnymi elementami ekosystemu. Sieć ta jest bardzo rozbudowana i wraz ze wzrostem liczby elementów ekosystemu, zwiększa się jej komplikacja ${ }^{17}$. Ten nieustanny proces obiegu pierwiastków w przyrodzie nazywa się cyklem biogeochemicznym.

Cykl biogeochemiczny, to krążenie materii w skorupie ziemskiej, hydrosferze $i$ atmosferze $w$ wyniku jednoczesnego działania sił natury geofizycznej (np. przemieszczanie się ogromnej masy wód) i biologicznej (np. fotosynteza) ${ }^{18}$. Do najważniejszych cykli biogeochemicznych należą obiegi: węgla, azotu, wody, tlenu, fosforu i siarki ${ }^{19}$. Cykle obiegu materii, ale także i energii, dokonują się głównie w dwóch zasadniczych rytmach: dobowym i roczny. Cykl dobowy związany jest $z$ obrotowym ruchem ziemi, a cykl roczny ze zmianą położenia Ziemi względem słońca. W rytmie dobowym zmienia się przede wszystkim temperatura, wilgotność i ciśnienie. W rytmie rocznym zmieniają się warunki klimatyczne, procesy hydrologiczne, glebowe, charakter roślinności i tryb życia zwierzą ${ }^{20}$. Jeśli $w$ tych cyklach nie ma nadmiaru lub braku pierwiastków biogennych, to ekosystem pozostaje we względnej równowadze dynamicznej. Stabilność ekosystemów wynika ze sprzężenia zwrotnego, jakie zachodzi pomiędzy poszczególnymi elementami ekosystemu. Sprzężenia dodatnie rozwijają strukturę systemu, natomiast towarzyszące im sprzężenia ujemne odpowiadają przede wszystkim za zachowanie równowagi i stabilność układu ${ }^{21}$. Tak

17 Miedzy elementami ekosystemu występującymi w liczbie $n$ może istnieć $(n 2-n)$ relacji dwukierunkowych, (np. dla 20 elementów tych relacji będzie aż 380). Natomiast lańcuchy troficzne, to są kanały przepływu materii i energii, np.: roślina- roślinożerca - drapieżca - (otoczenie), lub: roślina - roślinożerca - detrytus - destruent - (otoczenie). Zwykle cząstka materii przechodzi przez 1-4 ogniw lańcucha, rzadko więcej. Por. J. WEINER, Życie i ew'olucja biosfery..., dz. cyt., s. 195-196.

18 Por. tamże, s. 144-145; E. PAŁYGA-GUTOWSKA, Ekologia z ochronq środowiska..., dz. cyt., s. 55.

19 Por. J. DORST, Sita życia, PIW, Warszawa 1979, s. 27-28.

20 Por. A. RICHLING, J. SOL.ON, Ekologia krajobrazu..., dz. cyt., s. 103.

21 Stosunek sprzężeń (dodatnich i ujemnych) zmienia się w zależności od etapu rozwoju ekosystemu. W fazie początkowej przeważają sprzężenia dodatnie, a stopniowo wraz z rozwojem pojawiają się sprzężenia ujemne. Czyli w początkowym stadium rozwoju przebieg procesów jest szybki, a w miarę osiaggania stanu dojrzalego ulega spowolnieniu. Por. tamże, s. 104-105. 
więc w celu utrzymania równowagi ekosystemu, sprzężeniom zwrotnym dodatnim towarzyszą sprzężenia zwrotne ujemne i odwrotnie.

Obok zasobów energetycznych i materialnych, do podstawowych zasobów wewnętrznych ekosystemów należą także zasoby informacyjne. Informacja rozumiana ,jako transformacja jednego komunikatu asocjacji informacyjnej $\mathrm{w}$ drugi komunikat tej asocjacji"22 służy w ekosystemach zmniejszaniu niepewności danego zdarzenia w wyniku otrzymania sygna$\mathfrak{u}^{23}$. Obieg informacji w ekosystemach dokonuje się na różnych drogach. Najczęściej informacja jest przekazywana wewnątrz gatunku ze pomocą zapisu genetycznego. Przepływ informacji powoduje różnicowanie się form życia ${ }^{24}$. Informacja jest kodowana $\mathrm{w}$ wewnętrznej strukturze systemu $\mathrm{w}$ postaci pamięci. Pamięć, to zdolność danego obiektu do magazynowania otrzymanej informacji i do oddawania jej w miarę potrzeb ${ }^{25}$. Należy rozróżnić pamięć zewnętrzną i wewnętrzną elementów i całych systemów. Pamięć wewnętrzna związana jest $\mathrm{z}$ uporządkowaniem zmian odpowiadającym prawidłowościom zmian obiektów. Z pamięcią wewnętrzną związane są np.: w organizmie - proces rozwoju osobniczego, $w$ biocenozie - prawidłowości sukcesji pierwotnej. Pamięć zewnętrzna związana jest z zapamiętywaniem przeszłych stanów systemu i wpływem tych stanów na stan obecny. Jej elementami są np.: diaspory gatunków reliktowych, fragmenty zbiorowisk o charakterze naturalnym $w$ krajobrazie rolniczym itp ${ }^{26}$. W pamięci układu przyrodniczego dokonują się zmiany wraz z upływem czasu i w miarę docierania nowych informacji.

Wykorzystując informację nagromadzoną $\mathrm{w}$ pamięci, osobniki danego gatunku czy populacji mogą w sposób adaptacyjny dostosowywać się do warunków stwarzanych przez inne gatunki i całościowych warunków ukształtowanych wewnątrz ekosystemu do tego stopnia, że wielogatunkowe układy nabierają cech integralności i są w stanie przewidzieć ich przyszły $\operatorname{los}^{27}$. Wraz $\mathrm{z}$ dopływem i organizacją informacji wewnętrznej

22 J. MAZUR, Jakościowa teoria informacji, definicja. Cyt. za: M. LUBAŃSKI, Informacjasystem, w: Zagadnienia filozoficzne w'spótczesnej nauki. Wstęp do filozofii przyrody, wyd. IV, pod red. M. Heller, M. Lubański, Sz. W. Ślaga, Wyd. ATK, Warszawa 1997, s. 71.

23 Takim sygnalem jest zmiana oddziaływania lub parametru systemu w przestrzeni i czasie, rozpatrywana niezależnie od jego fizycznego nośnika. Za: A. RICHLING, J. SOLON, Ekologia krajobrazu..., dz. cyt., s. 35. Por. A. D. ARMAND, Modele informacyjne kompleksów przyrodniczych, „Przegląd Zagranicznej Literatury Geograficznej" 1979, nr 2.

25 W najprostszym przypadku pamięć jest równoznaczna ze zwiększeniem różnorodności stanów systemów. Por. A. RICHLING, J. SOLON, Ekologia krajobrazu..., dz. cyt., s. 35; W. R. ASHBY, An Introduction to Cybernetics, Wiley New York.

26 Por. A. RICHLING, J. SOLON, Ekologia krajobrazu..., dz. cyt., s. 35.

27 Por. J. STRZAEKO, Ekologia czlowieka, w: Kompendium wiedzy o ekologii, pod red. J. Strzałko i T. Mossor-Pietraszewskiej, PWN, Warszawa-Poznań 2001, s. 206. 
dokonuje się wzrost uporządkowania związany z jednoczesnym zmniejszaniem entropii układu. Jednak jednorazowy duży dopływ informacji $z$ zewnątrz, przy jednoczesnym ograniczonym poborze energii, może doprowadzić do wzrostu entropii i destrukcji całego systemu. Informacją zewnętrzną mogą być różne czynniki środowiska abiotycznego, w tym czynniki ograniczające, zjawiska zależne od zagęszczenia, alleopatyczne substancje chemiczne, pola magnetyczne a także sztuczne sygnały pochodzące $z$ antropopresji.

Zespół wszystkich procesów powodujących wymianę i transfer materii, energii i informacji utrzymuje względnie stałą równowagę organizmu czy też w szerokim kontekście całego ekosystemu. Mówiąc o równowadze ekologicznej, trzeba stwierdzić, że stan równowagi w pojęciu ekologicznym należy traktować bardziej jako fakt teoretyczny, który rzadko występuje $w$ naturze ${ }^{28}$. Dlatego też trafniejsze jest mówienie o równowadze dynamicznej ekosystemów Ziemi. W rzeczywistości żaden ekosystem nie jest absolutnie stały. Względna równowaga i stabilność ekosystemów podlega częstym amplitudom wahań pod wpływem zakłóceń zewnętrznych. W przyrodzie (ekosystemach) występują ciągle fluktuacje o charakterze niewielkich odchyleń od linii równowagi ale także zmiany ewolucyjine, długookresowe związane z procesami geologicznym czy genetycznymi ${ }^{29}$. Inną bardzo istotna, a w chwili obecnej chyba najważniejszą, przyczyną zachwiania dynamicznej równowagi układów przyrodniczych, jest oddziaływania antropogeniczne.

\section{Zagrożenia antropogeniczne}

Gatunek ludzki, który dzięki zdobyciu ognia, wynalezieniu narzędzi, dzięki rolnictwu, technice i nauce, zdobył swoistą autonomię w środowisku przyrodniczym, doprowadził w swojej działalności do poważnego naruszenia równowagi ekosystemów ziemskich. Każdy świadomy lub nieświadomy, celowy lub przypadkowy bodziec ludzki, określamy jako działanie antropogeniczne ${ }^{30}$. Niektóre $z$ tych działań antropogenicznych powodują zmiany środowiska przyrodniczego na stosunkowo niewielkich powierzchniach (przemysł, zabudowa miejska), inne przeobrażają środowisko przyrodnicze na znacznym jego obszarze (np. uprawy glebowe).

28 Por. K. LASTOWSKI, Fundanentalne przesłanki ekofilozofii, w: Edukacja środowiskow'a programy, metody, efekty, PAN, Komitet naukowy przy Prezydium PAN „Czlowiek i Środowisko", Instytut Badań Edukacyjnych, Zeszyty Naukowe 28, pod red. D. Cichy, Warszawa 2002, s. 86.

29 Por. K. LEDWOŃ, Ekologiczne podstawy ksztaltowania technosfery, PWN, Warszawa-Wrochaw 1998, s. 32.

30 Por. tamże, s. 38. 
Konfliktowy charakter interakcji człowiek-środowisko, wynika ze ścierania się przeciwstawnych tendencji: zachowawczej, stabilnej - środowiska przyrodniczego (ekosystemów) - i dynamicznej, aktywnej - wywołanej działalnością człowieka. Najogólniej działalność ludzką w przyrodzie można sprowadzić do trzech rodzajów ${ }^{31}$ :

- eksploatacji zasobów przyrody (głównie surowców energetycznych: węgla ropy naftowej, gazu ziemnego; pierwiastków promieniotwórczych; rud metali oraz niektórych surowców ceramicznych i budowlanych),

- przetwarzania pozyskanych zasobów (co wiąże się wprowadzaniem sztucznych obiektów w naturalne środowisko przyrodnicze i powoduje naruszenie, a nawet iszczenie pierwotnych elementów przyrodniczych),

- wprowadzanie do przyrody substancji lub czynników, będących ubocznymi produktami przetwarzania zasobów przyrody (substancje te są często bardzo groźne dla naturalnego środowiska i burzą jego równowagę).

W swojej działalności człowiek stwarza sam sobie nowe potrzeby, które $z$ kolei rodzą dalsze, i tak bez końca, co w wyniku prowadzi do radykalnych zmian w ekosystemach i wytwarza środowisko sztuczne, obce i nie kompatybilne $z$ naturalnym środowiskiem ekosystemów ${ }^{32}$. Drugi groźny dla równowagi ekosystemów objaw działalności człowieka, sprowadza się do nadmiaru informacji wprowadzanej przez niego do ekosystemów. Jest to informacja pozagenetyczna zapisana w kulturze. Informacja ta pozwala samoregulować się populacji ludzkiej, a jednocześnie umożliwia wprowadzanie do ekosystemów nowej materii i energii, co burzy dotychczasową przyrodniczą równowagę ekosystemu i prowadzi do powstania nowego rodzaju biocenozy (społeczności ludzkiej), tyle tylko, że biocenoza ta dysponuje pozaosobniczą informacją o swojej własnej strukturze. Ten rodzaj biocenozy można by nazwać antropocenozą. Jest to jedyna cenoza dysponująca informacją pozaosobniczą. W jej skład wchodzą - poza osobnikami naszego gatunku - elementy materialne, ożywione i nieożywione, uporządkowane zgodnie $z$ informacją kulturową ${ }^{33}$. Niekontrolowany $i$ nadmierny przepływ materii, energii oraz informacji, prowadzi do częścio-

31 Por. K. STEPCZAK, Ekologia stosowana, w: Kompendium wiedzy o ekologii, pod red. J. Strzałko i T. Mossor-Pietraszewskiej, PWN, Warszawa-Poznań 2001, s. 357-358; także: A. SAS-BOJARSKA, Elementy ekologiczne w' gospodarowaniu przestrzennym, „Gdański Biuletyn Proekologiczny" 1994, nr 10, s. 10.

32 Por. J. ŻUKOWSKI, Planeta ludzi, w: Dajcie szansę Ziemi, w'yboru tekstów' dokonat J. Zieliński, Książka i Wiedza, Warszawa 1971, s. 76.

33 Zob. J. STRZAŁKO, Ekologia czlowieka, w: Kompendium wiedzy o ekologii..., dz. cyt., s. 207. 
wej lub całkowitej blokady sprzężeń zwrotnych w ekosystemach. Antropocenoza $w$ sprzężeniach zwrotnych $z$ ekosystemami przyrodniczymi ma przewagę sprzężeń dodatnich i to prowadzi do zachwiania równowagi niemalże wszystkich ekosystemów ziemskich.

Mechanizmy antropogeniczne wspomagające równowagę ekologiczną z uwagi na potrzebę zachowania równowagi ekologicznej ekosystemów, podejmowane są różnego rodzaju działania sozologiczne, zmierzające do utrzymania bądź przywrócenia tejże równowagi. Istnieje wiele teoretycznych i praktycznych rozwiązań służących wypracowaniu korzystnych relacji antroposfery do biosfery. Dla przykładu można wymienić trzy najbardziej ogólne ${ }^{34}$ :

- podporządkowanie człowieka prawom i prawidłowościom przyrody (człowiek podlega tym samym prawom egzystencji i rozwoju co i inne gatunki biologiczne, dlatego musi zrezygnować $z$ technologicznej ingerencji w przyrodę i kształtowania jej według swoich celów i założeń - tak głosi skrajny ekologizm),

- dominacja człowieka nad przyroda (człowiek jest jedynym gatunkiem myślącym i posiadającym kulturę, dlatego też jest upoważniony do podporządkowywania sobie przyrody i zaspakajania jej kosztem swoich najróżniejszych potrzeb - to teza antropocentryzmu),

- homeostaza antropogeniczna (związki między człowiekiem a przyrodą powinny mieć charakter dynamiczny, a człowiek wraz z przyrodą może rozwijać się w sposób zrównoważony - ten pogląd można odnieść do filozofii zrównoważonego rozwoju).

Relacje między człowiekiem a przyrodą powinny opierać się na „trwałym współżyciu dwu (...) organizmów (w tym przypadku człowiek - przyroda) należących do różnych gatunków, korzystnym dla każdego z tych organizmów" ${ }^{\prime 35}$. Głównym zadaniem jest zachowanie ekologicznej infrastruktury i długookresowej integralności, a tym samym produktywności systemów podtrzymujących życie na Ziemi ${ }^{36}$. Ekosystemy z cała swoją złożonością i dynamicznością, ale także i ograniczonością przez prawa biologiczne, muszą być włączone w rozwój środowiska kulturowego. Z drugiej zaś strony, antropopresja nie może niszczyć ekologii ekosystemów lecz możliwie najlepiej je chronić i wspierać.

Utrzymanie przez człowieka równowagi ekologicznej ekosystemów, domaga się aby nie wprowadzać do środowiska przyrodniczego obcych jemu środków (głównie chemicznych) niszczących jego strukturę i funk-

34 Za: A. MALINOWSKI. Wstęp do antropologii i ekologii człowieka, Lódź 1994, s. 266-267.

35 S. JASTRZEBSKI, Nowy w'zorzec cywilizacji - ochrona śodowiska, Warszawa 1981, s. 92.

36 J. ŚLESZYŃSKI, Wskaźniki trwatego rozwoju, „Ekonomia i Środowisko” 1997, nr 2(11), s. 19 
$c_{j e ̨}^{37}$. W celu utrzymania dynamicznej równowagi ekosystemów zakłada się, że stopa eksploatacji zasobów odnawialnych nie może przekroczyć stopy ich regeneracji ( $<<y$ ), a ilość odpadów (zanieczyszczeń) odprowadzanych do środowiska przyrodniczego, nie może przekraczać jego zdolności asymilacyjnej $(\mathrm{W}<\mathrm{A})^{38}$. Równoważenie systemów przyrodniczych wiąże się także $z$ przepływem informacji. Tak jak to wcześniej było wspomniane, świat techniki stworzony przez człowieka, a usytuowany w środowisku przyrodniczym, nie posiada mechanizmów sprzężenia zwrotnego, co staje się przyczyną zachwiania naturalnej równowagi ekosystemów. W celu przywrócenia równowagi takiego systemu, potrzeba wielkiego potencjału intelektualnego i technicznego, który umożliwiłby nie tylko podnoszenie jakości życia ale i poprawę jakości otoczenia tego życia $^{39}$. Jest to ogólna propozycja kształtująca pewien ogólny schemat równoważenia procesów antropogenicznych z przyrodniczymi.

Systemy: społeczny i przyrodniczy, wchodzą w skład wielkiego systemu ziemskiego i pozostaję względem siebie w stosunku dynamicznym. To sprawia, że oba te systemy dadzą się odpowiednio kształtować. Człowiek kształtuje swoje środowisko życia w procesach produkcyjnych i gospodarczych. Aby w tym antropopresyjnym procesie ksztaltowania środowiska móc utrzymać dynamiczną równowagę ekosystemów, potrzeba pewnej kontroli i zwrotnego sprzężenia systemu gospodarczego z przyrodniczym. W sytuacji, kiedy system przyrodniczy będzie zbliżał się do stanu zagrożenia (wzrost entropii), wówczas gospodarka i przyroda powinny zamienić się miejscami. Układem centralnym w takiej sytuacji powinien być zagrożony ekosystem, który byłby wzmacniany i podtrzymywany przez systemy sztuczne. Gospodarka miałaby otoczyć środowisko przyrodnicze (ekosystemy) i w tej sytuacji zagrożenia pełnić funkcje opiekuńczą. Tej opiekuńczej funkcji gospodarki względem systemu przyrodniczego towarzyszyć będzie wzrost entropii dezorganizacji struktur gospodarczych. Dalszym przejawem będzie dyssypacja zasobów gospodarczych, zmiana struktury ich gospodarowania, przeznaczenie mniejszej części na cele produkcyjne i konsumpcyjne, a większej na ochronę środowiska przyrodniczego. Oznacza to wzrost jednej ze strzałek przepływu zakumulowanych zasobów ${ }^{40}$. Przepływy regenerujące środowisko przy-

37 Por. S. KOZŁOWSKI, Ekologiczne problemy przysztości śuiata i Polski, Komitet Prognoz „Polska w XXI wieku” przy Prezydium PAN, Dom Wyd. ELIPSA, Warszawa 1998, s. 119. Por. B. FIEDOR, System w'skaźników i indeksów ekorozwoju, w: Ekorozwój. Jego istota i możliwości wdrażania. Materiaty pokonferencyjne, (Międzynarodowe Targi Ekologiczne POLEKO '95, Poznań 23 listopada 1995 r.), s. [5] 79, (materiał powielony).

Por. R. DOMAŃSKI, Propozycja badań systemu środowisko przyrodnicze - gospodarka spoteczerístwo ze pomocq struktur dyssypatywnych, „Przegląd Geograficzny”, 1992,T. LXIV, z. 1-2, s. 29. 
rodnicze nie muszą być ekwiwalentne, powinny jednak być dostateczne, aby przywrócić systemowi przyrodniczemu dynamiczną równowagę lub zdolność samoregulacji ${ }^{41}$. Jest to bardzo ogólny mechanizm antropogeniczny wspomagający dynamiczną równowagę ekosystemów Ziemi.

Istnieje też szereg szczegółowych, konkretnych i doraźnych przykładów na zachowanie równowagi systemu przyrodniczego. Skuteczną drogą do osiągnięcia tego celu jest utrzymywanie dużej mozaikowatości (różnorodności) w strukturze pól uprawnych, łąk, zadrzewień, zbiorników wodnych, osiedli itp. Dopiero w takim systemie przyrodniczo-społecznym można przejść do regeneracji zachwianych struktur ekosystemowych. Aby utrzymać równowagę w ekosystemie należy:

- utrzymać różnorodność w strukturze przestrzennej, a szczególnie w gospodarce rolnej i sieci osiedleńczej,

- uksztaltować obieg wody w sposób stymulujący procesy filtracyjne i samooczyszczające dla poszczególnych zlewni cząstkowych,

- tworzyć nowe miejsca ostojowe dla roślin i zwierząt,

- dostosować zabiegi agrotechniczne do wlaściwości gleby,

- wprowadzić techniki bezodpadowe, szczególnie w systemach komunalnych, energetycznych, komunikacyjnych,

- wprowadzić formy turystyki i wypoczynku nie powodujące degradacji środowiska ${ }^{42}$.

Dalsza równowaga ekosystemów zależy od zmian, jakie muszą się dokonać $w$ dotychczasowym wzorcu rozwoju cywilizacyjnego. Nieograniczony wzrost produkcji i konsumpcji, powinien być zastąpiony nowym paradygmatem rozwoju społeczno-gospodarczego. Wspomagając równowagę ekosystemów Ziemi, od których zależy istnienie i trwanie życia oraz jakikolwiek rozwój, światowa gospodarka powinna ewoluować w następujących kierunkach: Najpierw produkować więcej ale zużywać mniej. W kolejnym etapie produkować tyle samo lecz zużywać mniej (będzie to możliwe przy ustabilizowanej liczbie ludności naszej planety). Ostatni etap zmian w ogólnoświatowej gospodarce powinien doprowadzić do produkowania mniej i zupełnie czego innego ${ }^{43}$. Są to dalekosiężne ale uzasadnione perspektywy utrzymania ładu ekologicznego i dynamicznej równowagi ekosystemów podtrzymujących rozwój życia na Ziemi.

41 Por. R. DOMAŃSKI, Modelowanie systemów ekologiczno-ekonomicznych, „Kosmos” 1993, nr 1(42), s. 160-161.

42 S. KOZŁOWSKI, Ekorozwoój. Wyzw'anie XXI n'ieku, PWN, Warszawa 2000, s. 191.

43 Por. S. KOZłOWSKI, Ogólne uw'arunkow'ania ekorozwoju, w: Sterow'anie ekorozw'ojem. Teoretyczne aspekty ekorozw'oju, t. 1., pod red B. Poskrobki, Wyd. Politechniki Bialostockiej, Białystok 1998, s. 99. 


\section{Zakończenie}

Od milionów lat procesy przyrodnicze podtrzymywały życie na Ziemi. W historii świata były różne zagrożenia i katastrofy, które realnie zagrażały istnieniu bioróżnorodności. Wiele gatunków musiało wyginąć. Ewoluowały ekosystemy, zmieniały swój wygląd i sposób funkcjonowania. Wygląd powierzchni Ziemi zmieniał się na skutek ruchów tektonicznych, wybuchów wulkanów, zlodowaceń i naturalnej sukcesji ekologicznej. Wszystkie te zmiany naruszały równowagę "wielkiego ekosystemu naszej planety". Z czasem jednak odbudowywały się nowe struktury funkcjonalne, w których życie ewoluowało na wyższy poziom organizacji. Przyroda potrafiła sama zadbać o ciągłość i rozwój tej niezwykłej osobliwości jaka jest życie.

Od kiedy jednak na horyzoncie dziejów pojawił się człowiek z nową sila swojego umysłu, naturalne procesy ekologiczne zaczęły podlegać niebywałej presji, która doprowadziła $\mathrm{z}$ czasem do poważnego naruszenia równowagi $\mathrm{w}$ wielu ważnych ekosystemach ziemskich. $\mathrm{W}$ obecnym momencie historii, utrzymanie dynamicznej równowagi ekosystemów Zie$\mathrm{mi}$, jest ważnym zadaniem, które staje nie tyle przed przyrodą, co przed człowiekiem. Chcąc istnieć i rozwijać się nadal, musimy to zadanie podjąć. Potrzebujemy dzisiaj nowej optyki, uwolnionej od wyłącznie instrumentalnego traktowania ekosystemów, a uwzględniającej sprzężenie rozwoju człowieka $z$ dalszym rozwojem przyrody i to $w$ horyzoncie długookresowym. Taką wizję kreśli idea zrównoważonego rozwoju, chcąc połączyć dalszy rozwój cywilizacyjny z zachowaniem walorów i wartości rozwojowych środowiska przyrodniczego. Koncepcja zrównoważonego rozwoju, która widzi dalszy rozwój człowieka nie tylko na poziomie biologicznym, lecz przede wszystkim intelektualnym i duchowym, ma na celu przede wszystkim zabezpieczenie i utrzymanie dynamicznej równowagi ekosystemów Ziemi. 
The keeping dynamic balance of ecosystems Earth. (Natural and anthropogenic mechanisms)

\section{SUMMARY}

Article comprehends analysis of biosphere and ecosystem notions and shows importance for dynamic balance of ecosystems such processes: physicchemical cases sustaining life on the Earth and anthropogenic threats of social and natural environment. 